\title{
Potensi Urban Toys Sebagai Reproduksi Komunikasi Budaya
}

\author{
Rani Chandra Oktaviani ${ }^{1}$, Yuliana R. Prasetyawati ${ }^{2}$ \\ 1,2 Institut Komunikasi dan Bisnis LSPR, Jakarta, Indonesia
}

\begin{abstract}
ABSTRAK
Perkembangan globalisasi membuat penetrasi budaya populer semakin meluas, secara simultan budaya lokal perlahan semakin tenggelam. Salah satu produk budaya populer yang juga berkembang di Indonesia adalah Urban Toys, masyarakat mulai menyukai dan membeli produk urban toys yang berasal dari luar negeri. Namun saat ini muncul artis lokal yang mulai membuat karya urban toys dengan membawa konsep budaya lokal. Melihat masalah dan fenomena tersebut, maka tertarik dilakukan penelitian ini yang bertujuan untuk menganalisis potensi urban toys sebagai proses reproduksi komunikasi budaya. Teori yang digunakan dalam penelitian ini adalah teori komunikasi budaya, dan reproduksi budaya dengan pendekatan kualitatif. Pengumpulan data dilakukan dengan wawancara mendalam dan FGD, serta dilakukan teknik kehandalan data melalui konfirmasi sumber, dimana objek pengamatan bukan hanya dari artis lokal pembuat urban toys saja, namun juga melibatkan pandangan masyarakat, akademisi dan Badan Ekonomi Kreatif. Hasil penelitian menemukan bahwa urban toys berpotensi menjadi artefak baru dari proses reproduksi komunikasi budaya Indonesia, dan salah satu peranya dapat menjadi media komunikasi budaya yang memiliki peran dalam kohesifitas antar generasi. Dapat ditarik simpulan dari hasil penelitian ini adalah bahwa karya urban toys lokal dinilai dapat menggambarkan praktik adaptasi budaya lokal, namun disisi lain itu masih pada tataran sentuhan konsep budaya, dan belum sepenuhnya dapat digunakan sebagai resistensi budaya populer. Sedangkan implikasinya adalah reproduksi budaya melalui urban toys, masih dalam proses pelanggengan distribusi budaya populer.
\end{abstract}

\begin{abstract}
The development of globalization makes the penetration of popular culture increasingly widespread, simultaneously the local culture is slowly sinking. One of the popular culture products that is also developing in Indonesia is Urban Toys, people start to like and buy urban toys products that come from abroad. However, at this time there are local artists who are starting to make urban toys by bringing the concept of local culture. Seeing these problems and phenomena, this research is interested to be conducted which aims to analyze the potential of urban toys as a process of reproduction of cultural communication. The theory used in this research is the theory of cultural communication, and cultural reproduction with a qualitative approach. Data collection was done by in-depth interviews and FGDs, as well as data reliability techniques through source confirmation, where the object of observation was not only from local artists making urban toys, but also involved the views of the community, academics and the Creative Economy Agency. The results found that urban toys have the potential to be a new artifact of the reproduction process of Indonesian cultural communication, and one of the roles can be a medium of cultural communication that has a role in intergenerational cohesiveness. It can
\end{abstract}

KEYWORDS Urban Toys; Cultural Communication; Cultural Reproduction. 
be concluded from the results of this study that the work of local urban toys is considered to be able to illustrate the practice of adaptation of local culture, but on the other hand it is still at the touch level of cultural concepts, and has not been fully used as resistance to popular culture. While the implication is cultural reproduction through urban toys, it is still in the process of perpetuating the distribution of popular culture.

\section{PENDAHULUAN}

Penelitian ini dilatarbelakangi dengan melihat adanya fenomena dan masalah nasional, adanya indikasi semakin lama masyarakat Indonesia lebih menyukai budaya asing dan budaya popular daripada budaya tradisional Indonesia. Budaya populer yang datang dari negara seperti Jepang, Korea dan China, mulai menggeser budaya lokal. Indonesia, salah satunya, negara yang turut menjadi pusat perkembangan fenomena budaya populer juga menjadi negara yang banyak mengkonsumsi beberapa produk budaya populer seperti produk musik dan drama Korea, seperti produk-produk lainnya seperti produk kecantikan, produk makanan, rumah makan, dan lainnya. (Ridaryanthi, 2014)

Salah satu yang menjadi produk budaya populer saat ini adalah urban toys. Mainan ini bukanlah produk konsumsi anak-anak melainkan menjadi suatu karya seni dan produk kreatif yang ditawarkan untuk orang dewasa. Urban toys diproduksi dengan nilai seni dan nilai jual yang tinggi sehingga menarik untuk dikonsumsi. Menurut salah satu seniman urban toys Indonesia yang juga mendapatkan respon yang baik dalam pembelian menyatakan bahwa, keberadaan urban toys sudah ada cukup lama namun masih terbatas di kalangan komunitas. Selain memiliki harganya yang cukup mahal dan peluang produksi yang terbatas membuat urban toys tidak banyak yang membelinya, namun saat ini di Indonesia sedang ramai-ramainya atau marak baik dari sisi produksi maupun pembelian dikalangan masyarakat. (Suryadharma, 2019)

Penetrasi penjualan urban toys di Indonesia juga semakin berkembang pesat dikarenakan teknologi media seperti sosial media dan munculnya toko online. Ada dua distribusi produk urban toys di Indonesia yang pertama, dipasarkan melalui platform media sosialnya seperti melalui Instagram, Facebook, YouTube hingga website resmi artis. Selain itu munculnya penjualan urban toys, di toko online seperti ebay, bigcartel, hingga dijual di toko online lokal seperti Tokopedia. Hal inilah yang semakin membuat penjualan dan konsumsi semakin berkembang tidak hanya dikalangan komunitas penyuka urbantoys saja, melainkan dapat diakses dan dibeli oleh khalayak umum.

Tren urban toys di Indonesia cukup berkembang dibanding tahun-tahun sebelumnya. Pada awalnya hanya marak di kota-kota besar, seperti di Jakarta dan Bandung. Namun sekarang, mulai banyak bermunculan dari kota Bogor, Surabaya, Pontianak, dan kotakota besar lainnya. Perkembangan dan konsumsi urban toys dikalangan masyarakat juga bisa melalui adanya event nasional dan internasional yang mengangkat tema mainan 
seperti diantaranya Indonesian Comicon, Pop Con Asia, Battle of Toys, Urban Toys Stage dan masih banyak event lainya. (Haievent, 2020) Dengan adanya event yang mengundang banyak kalangan tersebut, juga meningkatkan pembelian urban toys di Indonesia.

Ditengah hidupnya konsumsi mainan urban (urban toys) di Indonesia, justru muncul beberapa artis Indonesia yang mulai membuat karya yang berbeda, mereka mulai membawa idealismenya kedalam karya mainan yang dibuat. Beberapa artis lokal Indonesia berinisiatif untuk membuat produk urban toys sebagai komunikasi budaya. Beberapa artis menawarkan keautentikan ide dan visi dari karya yang dibuat, seperti salah satu artis urban toys Indonesia yang juga menjadi ketua komunitas Indonesian Art Toys, Syvia Tampi mengatakan bahwa ia lebih concern untuk karya yang bersifat detail. Sehingga akhirnya beberapa karya dibuat dengan mengambil corak budaya lokal seperti barong Bali, Gatotkaca, atau reog. (Kaltim Post, 2018) Perkembangan jumlah artis urban toys lokal semakin meningkat seperti pada komunitas urban toys di Jakarta, yakni Indonesian Art Toys, sudah telah beranggotakan 500 orang. (Yusrini, 2017)

Melihat adanya perkembangan urban toys di Indonesia, kemudian semakin bermunculan artis lokal yang berinisiatif membawa tema lokal dalam karya urban toys yang dibuat, menarik untuk diteliti bahwa adanya perpaduan konsep budaya lokal dengan menggabungkan dengan budaya populer yang di usung oleh seniman atau artis urban toys Indonesia. Melalui realitas tersebut, penelitian ini hendak melihat bagaimana sebenarnya potensi urban toys sebagai bentuk komunikai budaya lokal melalui artefak budaya populer. Penelitian ini juga mengambil asumsi realitas bahwa melalui kombinasi budaya populer dan budaya lokal bisa menjadi sebuah reproduksi budaya, atau proses dimana sebuah budaya mengalami produksi ulang sebagai bentuk adaptasi dan resistensi.

Sehingga dengan melihat adanya permasalahan sekaligus adanya unsur keterbaruan yang dibuat oleh para artis urban toys Indonesia, dapat dibuat pertanyaan penelitian; bagaimana potensi urban toys dalam proses reproduksi budaya Indonesia? Dengan mengacu pada pertanyaan penelitian tersebut, maka tujuan penelitian ini lebih ke arah: Pertama, menjelaskan dan menganalisis potensi urban toys sebagai proses reproduksi komunikasi budaya Indonesia. Kedua, mendeskripsikan peran dan kedudukan urban toys dalam proses reproduksi komunikasi budaya.

Berdasarkan pra-riset karya urban toys dinilai dapat menjadi produk budaya lokal yang merupakan hasil karya seniman artis dalam hal ini mewakili masyarakat Indonesia. Dengan menggandeng budaya populer, artis Indonesia mencoba mengkomunikasikan kembali budaya lokal melalui konsep dan gagasan karyanya. Melihat adanya perubahan peran dan fungsi mainan, yang tidak hanya sekedar sarana hiburan, maka tertarik untuk diteliti bagaimana toys berfungsi sebagai media dalam menyampaikan gagasan/konsep budaya. Konteks penelitian ini juga melihat urban toys dari sudut pandang ilmu komunikasi, dimana dari fenomena yang telah dipaparkan yaitu urban toys dapat menjadi 
sarana alternative dalam menyampaikan gagasan budaya. Memandang bahwa kajian urban toys ini dapat masuk keranah komunikasi, penelitian ini berusaha menjelaskan bagaimana proses komunikasi budaya yang berjalan dari artis urban toys dalam menuangkan ide dan gagasan sebagai bentuk penyampaikan pesan budaya. Di sisi lain penelitian ini juga akan melihat aspek kajian perbaduan budaya yakni budaya lokal Indonesia dan budaya populer yang dibuat oleh artis urban toys lokal, merupakan murni perubahan dan adaptasi budaya atau memiliki aspek lain seperti budaya lokal hanya sekedar sentuhan atau sebenarnya muatan budaya populer lebih kental dan dominan sebagai bagian pelanggengan berjalannya budaya populer.

Penelitian ini juga merujuk pada penelitian sebelumnya di negara lain yakni di negara Turki yang juga membahas produksi jenis mainan kontemporer dan taktik adaptasi budaya dipelajari untuk mencapai pemahaman yang komprehensif. Dalam penelitian sebelumnya mainan disampel, dikategorikan, dan dianalisis, baik dalam karakteristik desain maupun proses desain dan produksi. Sebagai hasilnya, berbagai contoh adaptasi budaya yang metodis, yaitu terjemahan, transliterasi, hibridisasi dan reproduksi, di mana perusahaan mainan memfasilitasi unsur-unsur budaya tradisional, populer dan global serta berbagai mode produksi untuk taktik NPD mereka. (Gürpınar, Yagou \& Öğüt , 2016)

Melalui latar belakang diatas ada dua hal yang menjadi urgensi penelitian ini yakni, pertama dilihat dari aspek pemaparan potensi produk kreatif anak bangsa dalam usaha mengkomunikasikan budaya lokal melalui proses reproduksi. Sedangkan yang kedua, melihat bahwa ada unsur menarik dari artis Indonesia yang menggandeng budaya populer sebagai media penyalur idealisme dan unsur pesan nasionalis. Sehingga nantinya penelitian ini diharapkan dapat berkontribusi dalam perkembangan fenomena budaya dan konseptual komunikasi budaya pada konteks di Indonesia.

State of the art dari penelitian ini mencoba melihat bahwa sebuah karya kreatif dalam hal ini urban toys, dapat dijadikan salah satu contoh proses reproduksi komunikasi budaya. Dengan membawa teori dan beberapa konsep yang menjadi acuan literatur, penelitian ini khas pada aspek keterbaruan objek kajian penelitian yakni melihat bahwa fenomena budaya lokal berkembang dan beradaptasi dengan budaya luar/populer hingga akhirnya diciptakan kembali dengan konsep yang lebih diterima. Sedangkan pemilihan objek didasarkan pada berkembangnya fenomena budaya melalui kajian urban toys yang berkembang di Indonesia. Penelitian ini juga melihat proses pembuatan karya urban toys dilihat dari perspektif komunikasi, dimana produksi urban toys pada dasarnya sama seperti proses berjalannya sebuah komunikasi. Baik dilihat dari aspek mikro ataupun makro yang mempunyai tujuan dan peran reproduksi komunikasi.

Komunikasi dan budaya didefinisikan sebagai konsep yang terkait erat dengan budaya bahasa manusia. Adapun yang menjadi tema budaya adalah berkaitan dengan kepercayaan, sistem, nilai dan artefak. Dalam proses transfer elemen budaya tersebut maka dilakukanlah proses komunikasi budaya. (García-Carbonell \& Rising, 2006) 
Budaya dapat didefinisikan sebagai sistem nilai dinamis dari unsur-unsur yang dipelajari dengan asumsi, konvensi, kepercayaan, dan aturan yang memungkinkan anggota kelompok untuk saling berhubungan dan dengan dunia untuk berkomunikasi dan mengembangkan potensi kreatif mereka. Tepatnya, budaya menghasilkan kohesi di dalam dan diferensiasi antar kelompok untuk memberikan masyarakat sebuah identitas dan perbedaan. Atas dasar definisi yang diuraikan dan terkait lainnya, kita dapat mengatakan budaya itu: produk dari interaksi sosial, menawarkan pola yang disetujui secara sosial untuk kebutuhan biologis dan sosial, bisa merupakan warisan sosial yang ditransfer dari satu generasi ke generasi lain dalam masyarakat tertentu, dipelajari oleh setiap individu dalam perjalanan pengembangan pribadinya, adalah salah satu penentu dasar kepribadian, bergantung pada keberadaannya pada keberlanjutan fungsi masyarakat dan tidak bergantung pada setiap individu atau grup. (Khan, Iqbal, \& Gazzaz, 2012)

Komunikasi budaya tidak hanya menjelaskan hubungan antara komunikasi dan aspek budaya melainkan memiliki peran yang secara tersirat ataupun tersurat. Berdasarkan hasil penelitian sebelumnya menjelaskan bahwa proses komunikasi sosial budaya menjunjung tinggi atas asas kesetaraan diantara peran komunikator dan komunikan. Bahkan perbedaan latarbelakang budaya antara komunikator dan komunikan dapat disikapi dengan baik sehingga tidak menimbulkan kesenjangan atau gagap budaya, disisi lain dinilai dapat memperkaya pengalaman. (Aw, 2015)

Peran komunikasi budaya dapat diterjamahkan sebagai bagian implementasi dalam proses komunikasi kaitannya dengan budaya, jika dikaitkan dengan konteks penelitian ini peran implementasi komunikasi sosial budaya dapat jabarkan sebagai berikut: Pertama, setiap individu dalam konteks sosial memiliki nilai-nilai budaya dan berhak menggunakan nilai tersebut dalam kehidupan sehari-hari. Dalam konteks individu komunikasi budaya dapat berperan sebagai komunikator dan komunikan yang saling berhubungan meskipun dalam latar belakang budaya yang berbeda. Kedua, melalui proses komunikasi bisa berperan tidak hanya untuk mengajarkan pengetahuan, tetapi juga dapat mendidik nilai-nilai baik sosial maupun budaya. Implementasi komunikasi kaitannya dengan budaya dapat bermakna bagi pengembangan manusia, sehingga dalam pertukaran informasi tidak hanya bermaksud sebagai transfer pengetahuan saja, tetapi juga memiliki peran dalam transfer nilai-nilai budaya. Ketiga, dalam melakukan komunikasi perlu memahami bagaimana karakteristik komunikan sehingga komunikator perlu berusaha menyesuaikan cara berkomunikasi dan karakteristik komunikan yang relevan. Komunikator yang baik diharapkan bisa memahami karakteristik komunikan agar dapat berjalan efektif. Dalam konteks ini peran komunikasi sosial budaya merupakan proses pertukaran informasi secara efektif dan kreatif. Keempat, Komunikasi secara terbuka diindikasikan oleh adanya peluang yang sama dari cara berkomunikasi antara komunikator dan komunikan untuk menyampaikan gagasan. Kefektifan komunikasi dapat didesain secara terbuka, hal ini tergantung dari kedua belah pihak, 
namun karena komunikator yang memegang kendali maka tanggungjawab terjadinya komunikasi yang sehat, terbuka dan efektif terletak di tangan komunikator. (Aw, 2015)

Sedangkan konsep pendukung dalam penelitian ini membawa konsep reproduksi budaya, salah satu pakar yang menjelaskan konsep ini adalah Jane Gaines yang menjelaskan bahwa sebuah budaya akan berevolosi mulai dari proses produksi budaya, reproduksi termasuk juga konsumsi dari budaya tersebut. (Negus \& Pickering , 2004) Reproduksi budaya juga melihat bahwa yang berkembang bukan hanya benda/artefak budayanya melainkan pemikiran dan gagasan dari budaya tersebut, salah satunya adalah reproduksi ketidaksetaraan kekuatan sosial.

"Culture is now seen as a determining, not just a determined, part of social activity, and therefore culture is both a significant sphere for the reproduction of social power inequalities and a major component of the expanding world economy" (Hartley, 2004)

Jika dikaitkan dengan objek kajian, penelitian ini melihat budaya merupakan bagian dari reproduksi pemikiran seperti pada ketidaksetaraan kekuatan sosial. Dapat diilustrasikan bahwa penyebaran budaya populer menunjukan adanya ketidaksetaraan kekuatan sosial, dominasi budaya populer menjadi konsentarasi tersendiri dan menjadikan budaya tidak sekedar hanya aktifitas sosial saja, melainkan ruang untuk memproduksi kembali kekuatan sosial berkembang.

Reproduksi budaya telah menjadi bagian dari ortodoksi studi dalam teori ideologi dan neo-Marxisme. Sementara itu beberapa pihak masih membahas tema ideologi dan determinasi struktural mapan ini dalam teori budaya. Banyak argument reproduksi budaya yang dikemukakan juga menghadapi tantangan kontemporer, seperti pada beberapa kajian yang membahas spektrum formasi budaya diantaranya termasuk peran gender, seni rupa, film, jurnalisme, pendidikan, konsumerisme, gaya, bahasa, dan sosiologi itu sendiri. (Jenks, 1993) Pengembangan konsep reproduksi budaya menunjukkan berbagai kemungkinan analitik dalam beberapa tradisi berteori sosial, sebagian besar kontributor adalah akademisi yang bekerja di bidang sosiologi studi komunikasi. Mereka semua telah mengajar dan memiliki minat penelitian berkelanjutan dalam sosiologi budaya dan studi budaya. (Jenks, 1993)

Term atau istilah 'reproduksi' adalah berkaitan pada hal-hal, aspek penting dari pembentukan modal budaya dalam seni visual, karena mereka adalah salah satu cara dimana itu tersebar dan dibedakan. Kedua, 'reproduksi' merujuk pada seni kontemporer mengandaikan pandangan fotografis/karya, yakni suatu kebiasaan salinan dengan aturan dan kebiasaan melihat yang tersirat yang mengarahkan pemirsa/yang melihat tertuju ke prioritas estetika tertentu. Konsep habitus, dengan penekanannya pada cara di mana agensi diwujudkan, merupakan pusat penyelidikan budaya Bourdieu; dalam hal ini memberikan wawasan teoretis tentang bagaimana mempelajari budaya, seperti dalam menggambarkan pada aturan implisit reproduksi fotografis/karya seni, sehingga individu dapat cenderung menambah modal budaya mereka. (Fyfe, 2004) 
Keadaan kedua, yang meliputi 'objek material dan media, seperti tulisan, lukisan, monumen, instrumen, dll, dapat ditransmisikan sebagai kepemilikan benda-benda di dalam dan lintas generasi (Bourdieu, 1997). Ini juga termasuk prasasti seperti reproduksi seni dan artefak. Prasasti sangat penting untuk pembentukan modal budaya. Ini adalah sarana di mana pengetahuan diangkat dari lokalitas dan ditransmisikan melintasi waktu dan ruang untuk dikonsumsi oleh individu yang hanya dapat bertemu satu sama lain melalui media prasasti dan yang telah memasukkan kapasitas untuk memahami makna yang tertulis. (Fyfe, 2004)

Dalam konsep reproduksi, orang harus mengingat apa yang menjadi teori iklim dominan tahun 1960-an, adanya gagasan "mutasi" telah menjadi kata kunci banyak sosiolog, terutama diantara mereka yang mengaku telah membedah efek dari media massa baru. Disatu sisi membuat lenyapnya perbedaan sosial dan 'akhir ideologi' yang percaya pada 'mobilitas' masyarakat dan kehancuran kelas, muncul juga anggapan akhirnya dan untuk selamanya memberi jalan kepada prestasi. (Bourdieu \& Passeron, 1990)

Sejalan dengan penjelaskan konsep tersebut, beberapa literature juga menjelaskan tentang teori reproduksi budaya yang dikemukakan oleh Bordieou. Teori ini menjelaskan hubungan antar kelas yang awalnya diterima begitu saja. Untuk selanjutnya masuk kedalam masalah-masalah seperti misalnya, perubahan apa dalam reproduksi budaya yang terjadi dengan perubahan (jika ada) dalam komposisi kelas dan kelompok dominan, atau dengan pertumbuhan ukuran kelas menengah (dengan cara apa pun ini harus dipahami secara teoritis), atau dengan perubahan sifat dan situasi kelas pekerja, atau bagian-bagiannya. Teori ini oleh beberapa penulis diterjemahkan sebagai tindakan pedagogik 'kelas dominan', yang dengannya kita dapat mengaitkan gagasan 'kontrabudaya', dan aspek subjek dapat dikembangkan lebih banyak di masa depan, bersama dengan diskusi teoritis tentang hubungan antar kelas yang berubah. (Bourdieu \& Passeron, 1990)

Teori ini juga memperlihatkan bahwa Bourdiou, berusaha merangkul semua jenis pendidikan apapun bentuknya dengan proposisi dan asumsinya yakni "Logic of Pedagogic Action" dan pernyataan ini memiliki efek bahwa reproduksi budaya berkaitan dengan sistem atau kondisi pendidikan. Tujuan utamanya Bourdieu menawarkan konsep 'reproduksi' juga sebagai suatu bentuk usaha memformulasikan proposisi generik untuk segala bentuk transmisi budaya di dalam segala bentuk formasi budaya. Namun pada kenyataannya, konsep tersebut baru menunjukan bagaimana sistem pendidikan saat itu di Prancis dan belum bisa bersifat universal. (Archer, 1993) Untuk itu dalam perkembangannya kajian teori ini dikembangkan oleh beberapa sosiolog dalam menilai reproduksi budaya kelas, pedagogi, feminisme, dan bahkan artistic field.

Jika mengacu pada teori dan konsep yang dibangun dalam kerangka pemikiran penelitian ini, maka dapat dihubungkan dengan kajian penelitian. Melihat fenomena dan realitas 
bahwa teori ini diharapkan dapat melihat proses pembelajaran dan adaptasi artis urban toys Indonesia terhadap karya mainan luar negeri. Sejalan dengan proses tersebut, asumsi utama dari teori reproduksi budaya Bourdieu juga melihat pada kondisi tetap berjalannya kelas dominan atau budaya dominan melalu struktur pembelajaran. Sehingga penelitian ini selain melihat adanya potensi adaptasi, pembelajaran, masuknya muatan lokal dalam budaya populer, juga ingin melihat apakah sebenarnya urban toys luar negeri masih tetap dominan. Dengan kata lain, melalui pembelajaran artis dan perubahan pola produksi karya apakah ternyata masih merupakan bagian dari pelanggengan budaya dominan atau dalam hal ini masih menyebarluaskan urban toys luar negeri. Sedangkan secara praktik, penelitian ini akan melihat potensi dan peran artis urban toys sebagai pelaku komunikasi budaya.

\section{METODOLOGI PENELITIAN}

Penelitian ini akan dilakukan dengan paradigma konstruktifis, dengan pendekatan kualitatif dimana penelitian akan menggali infomasi yang mendalam dan menyimpulkan menjadi beberapa uraian temuan penelitian. Adapun metode penelitian yang digunakan dalam penelitian ini adalah: 1) Fokus Group Discussion 2) Wawancara Mendalam 3) Pengamatan data Sekunder.

Penelitian ini akan memilih beberapa narasumber yang dapat dijabarkan sebagai berikut: Narasumber Utama: (1) Beberapa Artis Senior Urban Toys Indonesia. Narasumber ini dipilih karena beberapa diantaranya adalah pelopor berkembangnya urban toys di Indonesia. beberapa diantaranya pernah mendapatkan apresiasi dari perusahaan luar negeri untuk memperbanyak produk karyanya dan juga telah mendapatkan publikasi di media dalam dan luar negeri. (2) Ketua \& Anggota Komunitas Urban Toys Indonesia. Adapun Komunitas urban toys yang dipilih adalah IAT (Indonesian Art Toys).

Adapun narasumber pendukung dalam penelitian ini adalah: (1) Akademisi. Narasumber ini memberikan pandangannya terkait dengan potensi dari sudut pandang konseptual dan theoretical, seperti komunikasi budaya, perna dan potensi kedudukan budaya popular dalam menggandeng budaya tradisional. (2) Badan Ekonomi Kreatif. Penelitian ini juga mewawancarai pihak lembaga yang menaungi industri kreatif di Indonesia, sebagai konfirmasi terkait potensi perkembangan urban toys di Indonesia, penyebarannya serta kendala yang dihadapi dalam mempopulerkan karya urban toys yang membawa tema budaya Indonesia. (3) Media, penelitian ini mewawancarai media yang biasa meliput kegiatan event dan proses publikasi artis urban toys Indonesia. beberapa media yang akan diwawancara adalah media online dan media konvensional.

Untuk memastikan keterhandalan data penelitian digunakan triangulasi, dimana yang dipilih dalam penelitian ini adalah triangulasi sumber. Dimana triangulasi diartikan sebagai proses pengecekan data kualitatif yang diperoleh itu diuji dengan teknik 
verifikasi. (Imran, 2015) Penelitian ini mengambil 3 sumber, yakni pelaku dan penggiat urban toys, kemudian dikonfirmasi kepada fasilitasior dan regulator yakni Badan Ekonomi Kreatif, Akademisi yang akan membantu menjelaskan dari sisi konseptual kaitannya dengan komunikasi budaya serta media sebagai perangkat sosial dimasyarakat mengenai kepopuleran dari urban toys, khususnya di Indonesia.

Analisis data dilakukan dengan menggunakan tahapan anasis data Miles \& Huberman yakni dimulai dengan melakukan tahap orientasi atau tahap deskriptif: peneliti mendeskripsikan apa yang dilihat, didengar, dirasakan, ditanyakan. Tahap reduksi dan fokus: pada tahap ini mereduksi segala informasi yang telah diperoleh pada tahap pertama. Tahap seleksi: peneliti menguraikan fokus yang telah ditetapkan menjadi rinci atau paparan. Selanjutnya dilakukan penarikan kesimpulan dan verifikasi. (Rijali, 2018)

\section{HASIL DAN DISKUSI}

\section{Potensi urban toys sebagai artefak reproduksi budaya}

Hasil penelitian menemukan bahwa urban toys berpotensi menjadi artefak baru yang merupakan hasil dari proses reproduksi komunikasi budaya Indonesia. Reproduksi yang dimaksud adalah adanya proses pemikiran dan perpaduan budaya lain, dengan memasukan kembali budaya Indonesia. Urban toy dapat dijadikan komunikasi nonverbal, yang memiliki unsur simbolik budaya lokal.

Proses reporduksi ini merupakan bagian dari pembelajaran pelaku dalam hal ini adalah artis lokal urban toys, dalam melakukan resapan atas budaya yang masuk melalui teknologi. Hal ini bisa dilihat dari proses, mereka mengamati perkembangan urban toys di Luar negeri, kemudian mereka mengkonsumsi hingga akhirnya adanya proses perancangan dalam membuat urban toys secara mandiri. Yang perlu ditekankan dalam penelitian ini, berdasarkan narasumber ahli komunikasi budaya adalah bahwa urban toys bukanlah media baru namun merupakan cara baru dalam menyampaikan tema atau gagasan budaya Indonesia. Seperti yang disampaikan narasumber ahli komunikasi budaya sebagai berikut:

"Kita harus melihat kehadiran Urban Toys (UT) sebagai komunikasi nonverbal (artefak) etnik yang mengandung (tanda, ikon dll.) dari etnik tertentu. Peran media lama dan media baru yang sekarang harus didorong untuk memperkenalkan artefak budaya seperti UT itu. Jadi menurut saya UT bukan "media yang baru" dia tetap sebagai media budaya etnik - namun dengan cara baru, cara kita mengkomunikasikan dia melalui media baru agar dia menjadi budaya material popular."

Dari pernyataan narasumber diatas, ada pula penekanan bahwa urban toys selain dinilai sebagai cara baru dalam menyampaikan dan memperkenalkan budaya Indonesia, terlihat bahwa adanya potensi dari urban toys untuk membantu mensiarkan symbol budaya melalui materi populer. Tentunya dari pernyataan tersebut dapat dianalisis bahwa bukan 
hanya karya dan artefak yang menjadi wujud reproduksi budaya melainkan cara mengkomunikasikan budaya melalui konsep populer yang juga dinilai sebagai bagian proses reproduksi budaya. Jika dikaitkan dengan konsep reproduksi budaya hal ini termasuk bagian dari prasasti seperti reproduksi seni dan artefak. Prasasti atau karya budaya sangat penting untuk pembentukan modal budaya. Ini adalah sarana di mana pengetahuan diangkat dari lokalitas dan ditransmisikan melintasi waktu dan ruang untuk dikonsumsi oleh individu yang hanya dapat bertemu satu sama lain melalui media prasasti dan yang telah memasukkan kapasitas untuk memahami makna yang tertulis. (Fyfe, 2004)

Temuan penting lainnya dari penelitian ini, mengindikasikan adanya bahwa urban toys lokal yang mengadaptasi urban toys luar negeri, memungkinkan justru bisa menjadi budaya populer yang baru. Hal ini seperti yang dikatakan oleh pakar komunikasi budaya yang menjadi narasumber dalam penelitian ini berpendapat bahwa:

"... budaya popular" adalah budaya dari masyarakat yang sangat dipengaruhi oleh "tampilan budaya material" yang menjadi selera massa pada suatu waktu dan ruang tertentu. UT jika terus menerus dipopulerkan maka akan berubah mendorong masyarakat menjadikan pencaharian UT sebagai budaya popular. Jadi kira-kira dalam masyarakat ada situasi "demam etnis" - mencari dan terus mencari symbol-simbol etnik yang dilekatkan pada material lainnya. Masyarakat merasa tidak lengkap hidupnya jika dia tidak pakai symbol etnik, Karena dimana mana semua orang pakai symbol etnik.

Dari pernyataan tesebut bisa dianalisis menjadi dua interpretasi, yang pertama urban toys bisa berpotensi menjadi materi budaya. Dalam hal ini bisa mengajak dan mempengaruhi mayarakat untuk bisa mengukai kembali budaya lokal. Tentunya ketika artis urban toys bisa memberikan konsep karya yang kuat maka, dapat menggiring masyarakat akan kebutuhan "tanda". Dalam hal ini, ketika karya budaya di usung atau dibuat oleh artis urban toys Indonesia yang telah terkenal, maka artis tersebut bukan hanay sekedar mengkomunikasikan kembali melainkan menciptakan kebutuhan akan tanda atau simbol etnik Indonesia. Urban toys dinilai berpotensi sebagai identitas baru dan simbol etnik, yang saat ini menjadi salah satu karakteristik masyarakat pada era informasi. Simbol etnik justru dinilai sebagai citra tersendiri yang menjadikan pembuat dan penggunanya mempunyai persepsi ekslusifitas.

Kedua, disisi lain memungkinkan terjadi pengulangan produksi urban toys yang dikemas dengan nuansa budaya atau etnik, menjadi budaya populer kembali. Jika diamati ketika masyarakat mengkonsumsi urban toys hanya pada aspek kepopuleranya, dan bukan karna ketertarikan akan etnik maka bisa diinterpretasi bahwa reproduksi budaya yang terjadi adalah hanya sebagai perpanjangan daribudaya populer tersebut. Jika dikaitkan dengan teori Buordieu yang menawarkan konsep 'reproduksi' merupakan suatu bentuk usaha memformulasikan proposisi generik untuk segala bentuk transmisi budaya di dalam segala bentuk formasi budaya. Sehingga jika dikaitkan dengan hasil penelitian artis urban toys dalam membuat karyanya, disatu sisi melakukan pembelajaran akan penyesuaian budaya, namun disisi lain pada dasarnya hanya mempertahankan 
keberadaan budaya populer. Kaitan dengan teori Bordieou, berusaha merangkul semua jenis pendidikan apapun bentuknya dengan proposisi dan asumsinya yakni "Logic of Pedagogic Action" dan pernyataan ini memiliki efek bahwa reproduksi budaya berkaitan dengan system atau kondisi pendidikan. Disatu sisi pendidikan dan pemahaman mampu membuat perubahan, namun disatu sisi hanya merupakan proses transmisi budaya kelas dominan yang terjaga dalam formasi budaya. (Bourdieu \& Passeron, 1990)

\section{Potensi urban toys sebagai media komunikasi budaya.}

Selain menjadi artefak sebagai karya budaya, urban toys dengan membawa pesan budaya lokal jika dilihat sebagai aspek komunikasi dinilai dapat menjadi "media" komunikasi budaya. Hal ini menjadi karakteristik dari urban toys dalam komunikasi budaya melalui fungsinya sebagai simbol budaya. Urban toys bisa menjadi media simbolik, fungsi tersebut dapat dianalisis sebagai sarana komunikasi yang memiliki makna tersirat, baik untuk mengkomunikasikan konsep lokal maupun konsep budaya Indonesia yang sedang berkembang.

Gagasan komunikasi dari artis bisa di jadikan symbol komunikasi individu sedangkan konsep lokal yang dibawa bersamaan bisa interpretasikan sebagai identitas komunitas. Hal ini seperti yang disampaikan oleh narasumber yang menyatakan bahwa karya urban toys bisa menjadi media komunikasi budaya secara simbolik.

"Benar, UT (urban toys) merupakan "potensi" media komunikasi budaya. Sebetulnya dalam kategori simbolis, budaya masyarakat kita selama ini sudah menjadikan symbolsimbol budaya sebagai identitas baik identitas individu maupun identitas komunitas budaya."

Jika dikaitkan dengan ciri komunikasi budaya, pakar komunikasi budaya juga menyatakan bahwa bagian dari proses berkembangnya masyarakat adalah pola konsumsi, dimana masyarakat dengan sendirinya akan membentuk budaya baru yang tidak hanya menampilkan nilai budaya, melainkan juga memikirkan bagaimana produk budaya dapat diterima dan dikonsumsi oleh masyarakat lain. Budaya sendiri merupakan proses mencari identitas atau simbol yang dapat diterima masyarakat. Melihat hal ini karya urban toys dapat dinilai sebagai media untuk menyampaikan identitas budaya lokal.

Selain itu potensi urban toys sebagai media komunikasi budaya juga diperkuat oleh pernyataan dari badan ekonomi kreatif yang juga menyampaikan bahwa, karya tersebut sangat memungkinkan sebagai media komunikasi budaya, seperti yang disampaikan oleh narasumber sebagai berikut:

“...tentu saja urban toys bisa sebagai media sosialisasi dan komunikasi bagi warisan budaya yang ingin dikembangkan karena kita kan punya undang2 tentang kemajuan kebudayaan itu ada beberapa hal yaitu bagaimana objek kemajuan kebudayaan dalam hal ini objek tsb bisa dalam bentuk tari tradisional, ritual maupun objek untuk tentu saja dibudayakan, dilestarikan oleh para pelaku budaya nah disini ketika ada hal seperti ini 
(UT). Ini adalah pemanfaatan objek kebudayaan yang nantinya ujungnya akan juga turut melestarikan dan melindungi, karena saat ini teman-teman generasi milenial yang bisa mejadikan bentuk popular seperti ini dan akan lebih mudah mengkomunikasikannya"

Pernyataan tersebut dapat dianalisis bahwa urban toys memang berpotensi untuk menjadi media sosialisasi dan komunikasi budaya Indonesia. Segala objek yang berkaitan dengan nuansa etnik, seperti tarian, ritual, termasuk objek terntentu bisa dinilai sebagai media komunikasi. Jika dilihat urban toys yang merupakan berbentuk objek ini bisa menjadi media komunikasi secara visual.

Temuan lainya, menunjukan bahwa urban toys merupakan cara komunikasi kreatif yang memungkinkan dapat mensosialisasikan warisan budaya. Dengan optimis, Badan Ekonomi Kreatif Indonesia menyatakan bahwa, hal ini merupakan terobosan dari generasi milenial atau kaum muda dalam mengkomunikasikan budaya lokal. Tentunya dinilai sebagai cara komunikasi yang mudah diterima dan persuasif karena menggandeng materi populer. Dalam konteks ini menunjukan sebuah budaya akan berevolosi mulai dari proses produksi budaya yakni produksi karya, termasuk reproduksi dalam bentuk konsumsi dari budaya tersebut. (Negus \& Pickering, 2004)

Potensi urban toys sebagai media komunikasi juga menjadi konsentrasi dari artis urban toys, dimana mereka menyatakan bahwa secara idealis mereka mempunyai pandangan melalui karyanya mereka bisa mentransfer nilai lokal. Hal ini seperti yang disampaikan oleh salah satu narasumber yang merupakan salah satu artis senior urban toys Indonesia.

“...menjadi media bisa banget, kita memang berharap urban toys bisa menyampaikan gagasan kita tentang kondisi sosial budaya, untuk itu kita dan beberapa artis mulai membawa tema lokal, seperti ada karya muka tembok, yang itu bisa jadi platform, di Indonesia banyak kan dinding yang digrafiti, dicoret-coret, ketika dibuat urban toys, itu bisa merepresentasikan kondisi sosial budaya Indonesia. Terus dari artis bisa custom sehingga memungkinkan berbagai gagasan dan ide karya dari artis merupakan media komunikasi artis untuk menyampaikan kondisi lokal Indonesia, jadi kita ga hanya mengambil konsep atau ide artis dari luar negeri"

Dari pernyataan tersebut, dapat dilihat potensi urban toys sebagai media komunikasi, dengan berbagai macam pesan artis dalam menggambarkan realitas lokal Indonesia. Interpretasi ini jika dikaitkan dengan konsep reproduksi budaya juga menunjukan adanya perubahan. Perubahan apa yang dalam reproduksi budaya terjadi dalam komposisi kelas dan kelompok dominan, atau dengan pertumbuhan ukuran kelas menengah atau sub dominan. Secara teori ini juga dapat diterjemahkan sebagai tindakan pedagogik 'kelas dominan', yang dengannya kita dapat mengaitkan gagasan 'kontrabudaya', dan aspek subjek dapat dikembangkan lebih banyak di masa depan, bersama dengan diskusi teoritis tentang hubungan antar kelas yang berubah. (Bourdieu \& Passeron, 1990) 


\section{Peran Urban Toys Sebagai Kohesi Sosial.}

Berdasarkan hasil penelitian menunjukan bahwa kemunculan urban toys dan penggiat yang berusaha membawa tema budaya Indonesia mengarah pada adanya potensi perekat sosial, hal ini menjadi pandangan optimis bahwa perkembangan urban toys di Indonesia menstimuli idealisme dan independensi karya dan konsep dari artis pembuat. Masuknya mainan urban ke Indonesia yang merupakan bagian dari produk populer, di reproduksi oleh artis lokal dengan menambahkan unsur tradisional ataupun original konsep original dari artis Indonesia. Adanya pemikiran dari sejumlah artis dalam menciptakan karyanya dengan menggambarkan kondisi Indonesia, citra Indonesia, dan ada pesan tersendiri dari pembuatan karya dinilai dapat menjadi media komunikasi kreatif. Seperti yang disampaikan oleh narasumber akademisi: "Sangat bisa. Sebab, urban toys, sebagaimana mainan lain, dapat menjadi media komunikasi dan kohesi sosial."

Pernyataan tersebut menguatkan bahwa urban toys yang dikemas dengan perpaduan nilai budaya lokal dan materi populer bisa berpotensi sebagai alat perekat dan kohesi sosial. Dapat diinterpretasikan bahwa urban toys yang membawa tema lokal, bisa mengkomunikaskan budaya Indonesia ke budaya lain/luar negeri. Sehingga analisis yang pertama, urban toys dengan muatan lokal bisa menjadi cara komunikasi antarbudaya.

Sedangkan yang kedua, bisa diamati bahwa urban toys bisa menjadi media perekat antar generasi. Seperti yang disampaikan oleh pihak Badan Ekonomi Kreatif, dikatakan bahwa urban toys yang banyak di buat oleh generasi milenial, dapat melestarikan budaya Indonesia melalui lintas generasi. Jika melihat interpretasi ini, maka secara konseptual peran urban toys merupakan proses komunikasi tidak hanya untuk mengajarkan pengetahuan, tetapi juga dapat mendidik nilai-nilai sosial maupun budaya. Implementasi komunikasi kaitannya dengan budaya dapat bermakna bagi pengembangan manusia, sehingga dalam pertukaran informasi tidak hanya bermaksud sebagai transfer pengetahuan saja, tetapi juga memiliki peran dalam transfer nilai-nilai budaya. (Aw, 2015)

Interpretasi ini juga relevan dengan konteks konsep budaya, dimana dalam perkembangan budaya bisa menghasilkan kohesi didalam dan diferensiasi antar kelompok, untuk memberikan masyarakat sebuah identitas dan perbedaan. Dari definisi yang diuraikan dan terkait lainnya, dapat juga mengatakan budaya itu sebagai produk dari interaksi sosial, suatu pola yang disetujui secara sosial untuk kebutuhan sosial, dan bisa merupakan warisan sosial yang ditransfer dari satu generasi ke generasi lain dalam masyarakat tertentu, dipelajari oleh setiap individu dalam perjalanan pengembangan pribadi atau hasil pembelajaran. (Khan, Iqbal, \& Gazzaz , 2012)

Peran urban toys sebagai kohesi sosial juga dinyatakan oleh narasumber dari perwakilan media, yang menyatakan bahwa salah satu potensi perkembangan urban toys di Indonesia dapat menjadi perekat sosial baik dinilai dalam perspektif ekonomi ataupun sebagai media komunikasi pada aspek sosial, politik dan budaya untuk kondisi Indonesia 
seperti misalkan urban toys bisa menjadi kritik sosial ataupun politik. "...urban toys bisa jadi potensi sebagai perekat sosial, potensi ekonomi, bahkan bisa menjadi alat komunikasi politik sebagaimana narasi Game of Thrones"

Dari sudut pandang media, mereka menilai bahwa adanya perkembangan urban toys di Indonesia meskipun belum terlalu maju dan menjadi publikasi utama, namun melihat peluang dan potensinya kedepannya dapat menjadi produk yang memiliki unsur berita. Hal ini disebabkan karya yang berkaitan dengan konsumsi publik, serta adanya kaitan dengan gaya hidup, akan menjadi pemberitaan yang menarik. Untuk saat ini mungkin dinilai belum marak, karena memang para pelaku belum banyak mengexpose karyanya dengan masif, sehingga terkadang media kurang menangkapnya. Berikut pernyataan dari pihak media bahwa karya urban toys memiliki potensi yang memiliki news value tersendiri.

"Lagi-lagi kembali pada poin news value di dalamnya. Nilai berita ini menyangkut kepentingan publik dan juga perkembangan publik itu sendiri. Ketika percampuran budaya tadi menjadi gaya hidup, tentu nilai beritanya tinggi sehingga layak diberitakan."

Berdasarkan hasil penelitian menunjukan bahwa adanya temuan yang cukup signifikan, dari pembuatan karya urban toys, khususnya yang dibuat secara original oleh artis urban toys Indonesia. Kata kunci komunikasi budaya yang kreatif mendorong adanya kohesifitas antar generasi, dimana nilai budaya lokal dapat dijembatani oleh media komunikasi urban toys. Melalui karya artis lokal yang mengangkat kembali tema lokal dengan menggandeng sentuhan modern dapat menjadikan budaya Indonesia yang mulai ditinggalkan, berpotensi untuk kembali digemari dan bahkan menjadi trend baru.

Jika dikaitkan dengan literature yang membahas mengenai peran komunikasi budaya artis urban toys dapat menjadi seorang komunikator. Sebagai komunikator dapat di Interpretasikan adanya upaya pembelajaran budaya, dan proses komunikasi efektif. Dalam konteks ini peran komunikasi sosial budaya merupakan proses pertukaran informasi secara efektif dan kreatif. (Aw, 2015)

\section{SIMPULAN}

Penelitian menyimpukan bahwa urban toys memiliki beberapa potensi diantaranya; berpotensi menjadi artefak sebagai bagian dari reproduksi komunikasi budaya Indonesia, kemudian juga urban toys dinilai menjadi efektif sebagai media komunikasi budaya, selain dinilai manarik dan kreatif dalam melestarikan budaya sedangkan dalam perannya sebagai media komunikai budaya urban toys khas untuk membangun kohesifitas antar generasi. Hasil penelitian ini menunjukan bahwa karya urban toys lokal dinilai dapat menggambarkan praktik adaptasi budaya lokal, namun disisi lain itu masih pada tataran sentuhan konsep budaya, dan belum sepenuhnya dapat digunakan sebagai resistensi budaya populer. 
Sedangkan implikasinya adalah reproduksi budaya melalui urban toys, masih dalam proses pelanggengan distibusi dan produksi budaya populer. Implikasi lain yang bisa ditarik dari penelitian ini menunjukan bahwa komunikasi budaya dapat berubah dan bertransformasi. Karya urban toys lokal dinilai dapat menjadi suatu bentuk komunikasi budaya yang baru, yang telah beradaptasi dengan budaya populer. Tentunya perubahan ini terjadi akibat dari adanya perkembangan teknologi dimana orang dapat melihat, mengamati budaya luar, hingga akhirnya mengadopsi budaya tersebut, yang menjadi khas adalah ketika masyarakat Indonesia dalam hal ini adalah artis dan komunitas, memproduksi symbol dan bahasa baru melalui karya urban toys.

\section{DAFTAR PUSTAKA}

Archer, M. (1993). Bourdiou Theory of Cultural Reproducation. Sage Journal, 225-240.

Aw, S. (2015). Implementasi Teori Komunikasi Sosial Budaya dalam Pembangunan Integrasi Bangsa. INFORMASI Kajian Ilmu Komunikasi Volume 45. Nomor 1., 65-72.

Bourdieu, P., \& Passeron, J. C. (1990). Reproduction in education, society and culture (Vol. 4). Sage.

Fyfe, G. (2004). Reproductions, cultural capital and museums:. London: Leicester University Press.

García-Carbonell, A. \& Rising, B. (2006). Culture and communication. College of Management Georgia Institute of Technology Atlanta Journal, ISSN 13987099773617 , 23-40.

Gürpınar, A., Yagou, A., \& Ögüt, Ș. T. (2016). Tactics of cultural adaptation: Design and production characteristics of toys in Istanbul. The Design Journal, 19(3), 451-472.

Haievent. (2020, Mei 1). www.haievent.com/tag/pameran-mainan-jakarta/. Retrieved from www.haievent.com: https://www.haievent.com/tag/pameran-mainan-jakarta/

Hartley, J. (2004). Communication, Cultural And Media Studies. London: Routledge.

Imran, H. A. (2015). Penelitian Komunikasi Pendekatan Kualitatif Berbasis Teks. Jurnal Studi Komunikasi dan Media Vol. 19 No. 1 (, 129 - 139.

Jenks, C. (1993). Cultural Reproduction Routledge. New York: Routledge.

Kaltim Post. (2018, Juli 1). kaltim.prokal.co/read/news. Retrieved from kaltim.prokal.co: https://kaltim.prokal.co/read/news/334614-berseni-lewat-mainan-layak-koleksi.html

Kamil, A. (2012). Gelombang Korea Menerjang Duni. Jakarta: Kompas.com.

Khan, F. R., Iqbal, Z., \& Gazzaz, O. B. (2012) Communication and Culture: Reflections on the Perspectives of Influence. Wulfeina Journal , 197-212.

Negus, K., \& Pickering, M. J. (2004). Creativity, communication and cultural value. New Delhi, India: Sage Publications. 
Ridaryanthi, M. (2014). Bentuk Budaya Populer dan Konstruksi perilaku Konsumen . Jurnal Visi Komunikasi, Volume 13, No. 01, 88-104.

Rijali, A. (2018). Analisis Data Kualitatif. Jurnal Alhadharah, Vol. 17 No. 33, 81-95.

Storey, J. (2015). Cultural Theory and Popular Culture. United Kingdom: Pearson.

Suryadharma, D. (2019, 7 29). https://www.brilio.net/creator. Retrieved from www.brilio.net: https://www.brilio.net/creator/4-fakta-urban-toys-mainan-unik-yang-disukai-orangdewasa-3c0e07.html

Yusrini, F. (2017, Februari 17). www.femina.co.id/trending-topic. Retrieved Maret 9, 2018, from www.femina.co.id: https://www.femina.co.id/trending-topic/serunya-para-kolektorberburu-urban-toys-? $\mathrm{p}=2$ 